\title{
Characterization and Optimization of Amylase Producing Bacteria Isolated from Solid Waste
}

\author{
Amalesh Samanta*, Debmalya Mitra, Sudipendra Nath Roy, Chandrima Sinha, Pinaki Pal \\ Division of Microbiology, Department of Pharmaceutical Technology, Jadavpur University, Kolkata, India. \\ Email: *asamanta61@yahoo.co.in
}

Received April 13 ${ }^{\text {th }}, 2013$; revised May 15 ${ }^{\text {th }}, 2013$; accepted June $12^{\text {th }}, 2013$

Copyright (c) 2013 Amalesh Samanta et al. This is an open access article distributed under the Creative Commons Attribution License, which permits unrestricted use, distribution, and reproduction in any medium, provided the original work is properly cited.

\begin{abstract}
Municipal waste is one of the most hazardous components of developing countries. However, enzymes do provide an eco-friendly solution in this case. Amylase is an important enzyme in food, textile and pharmaceutical industry and can be used for bioconversion of waste. From the municipal solid waste we have isolated an amylase producing bacteria that can grow in the irritant municipal waste and help in their bio conversation. The bacteria were identified as Cronobacter sakazakii Jor52 $\left(\mathrm{C}_{2}\right)$. The optimized media for maximum amylase production after $24 \mathrm{~h}$ of incubation, contains $2 \%$ starch, $0.6 \%$ peptone, $0.01 \% \mathrm{CaCl}_{2}, 0.05 \% \mathrm{KCl}, 0.05 \% \mathrm{MgSO}_{4}$ and $0.05 \% \mathrm{~K}_{2} \mathrm{HPO}_{4}$. The crude enzyme activity and stability study revealed that the amylase is stable within the $\mathrm{pH} 6-8$ and temperature $30^{\circ} \mathrm{C}-40^{\circ} \mathrm{C}$ and give maximum activity at $37^{\circ} \mathrm{C}$ at $\mathrm{pH}-8$.
\end{abstract}

Keywords: Amylase; Microbial Enzymes; Municipal Waste; 16S rDNA Sequencing; Cronobacter sakazakii

\section{Introduction}

Mostly, we all are habituated with good-morning whistle of municipal "waste" collectors. The term "waste" can be defined as: Unwanted, useless discarded materials without any sufficient value [1]. Regarding the fate of this huge Municipal Solid Waste (MSW), Environment Protection Agency (EPA) specifies that in 1989, 10\% was being recycled, $80 \%$ gone into landfills, and remaining $10 \%$ had incinerated. In a developing and industrialized nation like India, the solid waste generation (0.7 to 1.8 $\mathrm{kg} /$ person/day) is much higher than that of low-income nations (0.4 to $0.6 \mathrm{~kg} /$ person/day) [2-4]. These solid wastes have disparate deleterious effects on plants and animals thereby perturb our biosphere. So, waste management is prima facie concern for environmentalists for tackling the aggravating pollution rate. Need of an exigent eco-friendly solution is outright. Eventually, biodegrading enzymes can bolster any waste management program to achieve a consummate dominion over the produced MSW. In fact, enzymes can serve as an important molecular device for bioconversion of hazardous waste into bio-friendly compost which can be used to fertilize the soil, without affecting the ambiance. When

\footnotetext{
"Corresponding author.
}

the most striking characteristics of enzyme that is catalytic power and specificity taken into account; amylase is one of the important biocatalyst. Amylases catalyze the hydrolysis of alpha-1,4-glycosidic linkages of polysaccharides to yield dextrin, oligosaccharides, maltose and D-glucose. Mainly three types of amylases are found differing in the glycoside bond they attack- $\alpha, \beta$ and $\gamma$ amylases. Although they can be isolated from different source like animal, plant and microorganism, the microbial amylases are more thermostable and have higher yield [5]. Diverse fungal strains are able to produce amylase both intracellularly and extracellularly depending upon the fermentation process [6-8] but bacteria are the preferred source not only because maximum amount of generated enzyme within a very short time period but also due to its extracellular production attribute, which are indeed, easy to isolate [9-11]. Hence, bacterial amylases can provide an exquisite alternative to the chemical hydrolysis of starch [12]. In fact, bacterial amylase already gained profound importance in the field of biotechnology, textile industry, food processing and pharmaceutical industry [13] these amylase producing bacteria can be utilized for waste management as well. But as the municipal waste consists of different toxic metal ions, radioactive materials and other irritant chemicals, most 
microbes can neither show proper growth nor enzyme production for waste bio-conversion in this adverse condition. To outmaneuver this predicament, we have used the municipal waste as a source of amylase producing bacteria so that the isolated strain will be able to tolerate the detrimental condition of municipal waste and produce enough amylase for their transformation. Interestingly, for the first time, we were able to successfully isolate an amylase producing bacteria from solid waste that can be utilized in large scale waste management. We identified and characterized the bacterial strain and optimized the growth conditions. The activity and stability patterns for the crude enzyme isolated from the bacterial strain were also been reported.

\section{Material and Method}

\section{Isolation and Identification of the Bacteria}

In the present study the bacterial strain was being isolated from the municipal solid waste collected from "Dhapa", Kolkata and by dissolving $100 \mathrm{mg}$ in $10 \mathrm{~mL}$ sterile water before spreading on $1 \%$ starch and $2 \%$ agar containing media. The colonies those gave clear zone when flooded with gram iodine solution were selected as amylase producing bacteria [14]. Colonies of isolated plate were transferred by replica plating on to starch agar plate for obtaining pure culture and the bacteria showing highest amylase activity was selected for next step of studies.

Gram staining, biochemical and other morphological tests were performed for identification of bacteria [15]. The $16 \mathrm{~S}$ rRNA based molecular techniques were also used for further confirmation and data were submitted to National Center for Biotechnology Information (NCBI).

Media: Primarily three different media were selected, Media I (Peptone-2\%,Yeast extract-1\%, NaCl-1\%, Starch$1 \%$ and Agar-2\%), Media II (Starch-1\%, Yeast extract$0.2 \%$, Peptone- $0.5 \%, \mathrm{MgSO}_{4}-0.1 \%$, NaCl- $0.1 \%, \mathrm{CaCl}_{2}-$ $0.02 \%$ and Agar-2\%), Media III (Peptone- $0.6 \%, \mathrm{MgSO}_{4}{ }^{-}$ $0.05 \%$, KCl-0.05\%, Starch- $1 \%$ and Agar-2\%). The media helped to yield maximum amylase productivity was selected as basal media.

Culture condition and growth kinetics: To study the effects of $\mathrm{pH}$ and temperature change on enzyme production and growth of the organisms, the organisms were grown in the basal media at different $\mathrm{pH}$ at $37^{\circ} \mathrm{C}$ and then at $\mathrm{pH} 7$ at disparate temperature. The optimum temperature and $\mathrm{pH}$ for maximum enzyme production were obtained after working out a series of experiments for the bacterial stain. Various carbon compounds were added to the culture media for observing their effects on amylase production. The carbon source giving the maximum amylase production was then mixed at different concentrations for getting the optimum concentration of sole carbon source [16]. Similarly the effect of different inorganic and organic nitrogen sources and phosphate sources were studied by adding them in the basal medium at diverse concentrations. Additionally, the effects of different metal ions on growth and amylase production were observed by substituting the metal source $\mathrm{MgSO}_{4}$ of the basal medium.

Effect of $\mathbf{p H}$ and temperature on enzyme activity and stability: The $\mathrm{pH}$ optimum of the enzyme was determined by varying the $\mathrm{pH}$ of the assay reaction mixture using following buffers $(0.1 \mathrm{M})$ : sodium acetate $(\mathrm{pH}-4)$, sodium phosphate ( $\mathrm{pH}-6)$, potassium phosphate $(\mathrm{pH}-7)$, Tris $\mathrm{HCl}(\mathrm{pH}-8)$ and glycine $\mathrm{NaOH}(\mathrm{pH}-10)$. Similarly, the optimum temperature was evaluated by measuring the amylase activity at different temperatures $\left(30^{\circ} \mathrm{C}\right.$ $50^{\circ} \mathrm{C}$ ). To determine the stability the enzymes were preincubated at different buffers and different temperatures for $24 \mathrm{~h}$ to determine the residual enzyme activity.

Crude enzyme preparation and assay of amylase: To obtain the crude enzyme $24 \mathrm{~h}$ old cultures were transferred to micro-centrifuge tubes and centrifuged at 4000 rpm for 15 min. Cells were discarded and resultant supernatant was used as crude enzyme for various enzyme assay as described by Andrew D. Jamieson et al. [17]. The determination of amylase concentration of an unknown sample was made by plotting the absorbance of the reaction product at $470 \mathrm{~nm}$ against a standard amylase preparation. Units of amylase activity were expressed as micromoles of maltose liberated per minute.

\section{Results and Discussion}

Isolation and characterization: In the present investigation, we have successfully isolated a pure bacterial strain from municipal waste. The maximum amylase activity was found in medium III which is lower than the values found for Bacillus subtilis [18] and B. licheniformis [19], however this value was higher than that reported for B. coagulans, B. circulans [20], Aeromonas sp. and Pseudomonas sp. [21]. The identifications of the bacterial strain by $16 \mathrm{~S}$ rRNA based molecular techniques revealed that the bacterial strain is Cronobacter sakazakii Jor52 (GenBank Accession No. HM637744) which was denoted as $\mathrm{C}_{2}$ in our report. The morphological, biochemical and cultural studies showed (Table 1) that all attributes of the bacterial strain $\left(\mathrm{C}_{2}\right)$ matches the character described in BERGEY'S manual systemic bacteriology.

Media optimization and growth kinetics: In the present study we found $37^{\circ} \mathrm{C}$ as the optimum growth temperature for the presently reported $\mathrm{C}_{2}$ strain; higher temperature $\left(45^{\circ} \mathrm{C}\right)$ did not support any colonies (Figure 1). This may be due to the mesophilic nature of the spe- 
Table 1. Characterizations of Pseudomonus aeruginosa $\left(\mathrm{C}_{1}\right)$.

\begin{tabular}{ccc}
\hline SI No. & Tests & $\mathrm{C}_{2}$ \\
\hline 1 & Gram staining & Gram negative \\
2 & Size & Rod \\
3 & Colour (pigment) & White \\
4 & Motility & Motile \\
5 & Starch hydrolysis & + \\
6 & Protein hydrolysis & - \\
7 & Citrate utilization & + \\
8 & Urea hydrolysis & - \\
9 & Indole production & - \\
10 & Methyl red test & - \\
11 & VP test & + \\
12 & Nitrate reduction & + \\
13 & Gelatin liquification & - \\
14 & Catalase & - \\
15 & Oxidase & + \\
16 & TSI media & + \\
17 & SIM media & - \\
& & +
\end{tabular}

Sugar fermentation

(glucose, sucrose, galactose, maltose, Acid + Gas lactose and mannitol)

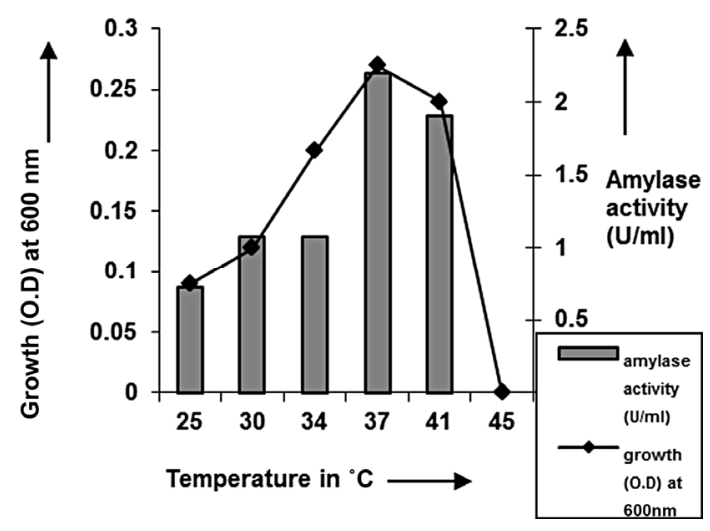

Figure 1. Temperature optimization of $\mathrm{C}_{2}$.

cies. As per earlier report [22] the high temperature may inactivate the expression of gene responsible for the starch degrading enzyme. Most of the starch degrading bacterial strain revealed a $\mathrm{pH}$ range between 6.0 and 7.0 for normal growth and enzyme production [23]. The presently isolated strain also exhibited optimum growth at $\mathrm{pH} 7$ (Figure 2). The composition and concentration of media greatly affect the growth and production of extracellular amylase production in bacteria [24,25]. Starch is omnipresent and is an easily accessible source of energy [26]. We also observed increasing the starch concentration increase both growth kinetics and amylase production up to certain extent then declines (Figures 3 and 4). Similarly peptone is the best nitrogen source for amylase production for the bacteria though beef extract supported the maximum growth (Figures $\mathbf{5}$ and $\mathbf{6}$ ). Also Adenosine mono phosphate upkeeps the maximum growth; the amylase production is the maximum for $\mathrm{K}_{2} \mathrm{HPO}_{4}$ (Figure 7). We have also figured out that, maximum growth and amylase production occurred in presence of calcium ion and the bacteria had significant heavy metal tolerance as well (Figure 8). The standard medium lacking starch did not produce amylase [27]. Glucose did not support amylase production presumably due to the catabolic repression by these sugars in the growing cells but starch considerably induced amylase synthesis $[28,29]$. Enzyme production by the microorganism is directly correlated to the time period of incubation [30]. In our study it was found that the bacteria yielded maximum amylase after $24 \mathrm{~h}$ of incubation and then the productions decline may be due to the utilization of all necessary nutrients (Figures 9 and 10); but the amylase production is non-growth related [31]. The differences in nutritional requirements of various amylase producing organisms or microbial strains could be attributed by the difference in their genetics.

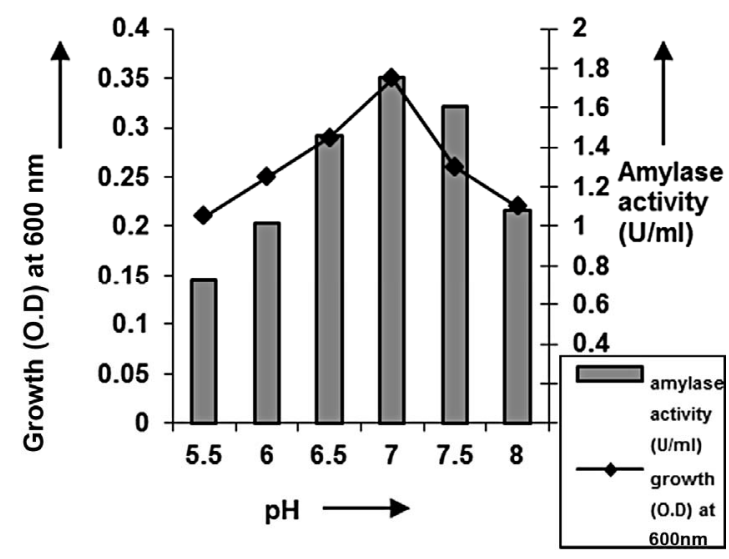

Figure 2. $\mathrm{pH}$ optimization of $\mathrm{C}_{2}$.

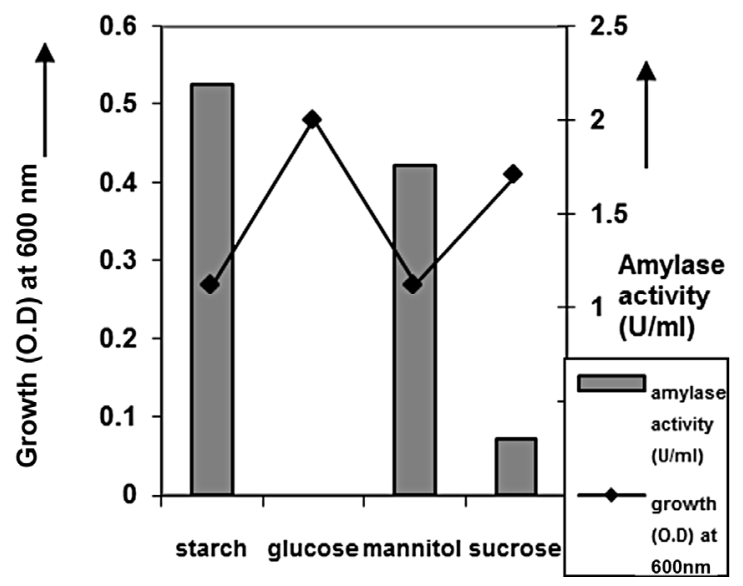

Figure 3. Carbon source optimization of $\mathrm{C}_{2}$. 


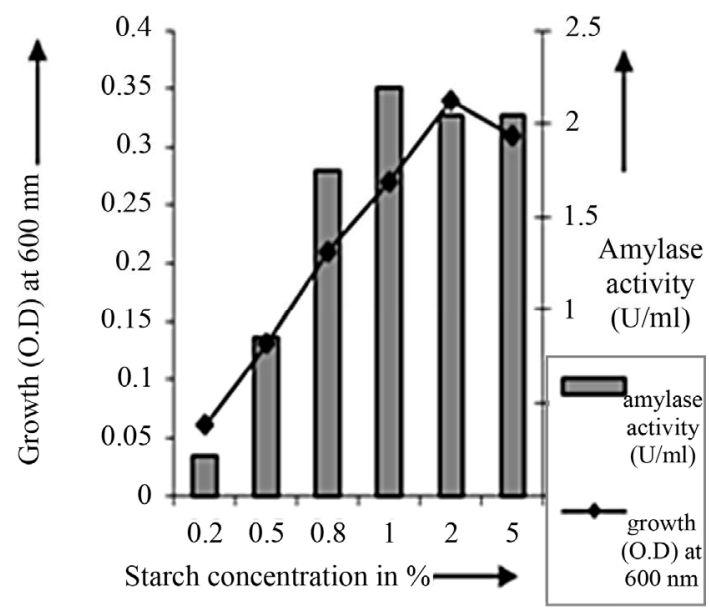

Figure 4. Starch concentration optimization of $\mathrm{C}_{2}$.

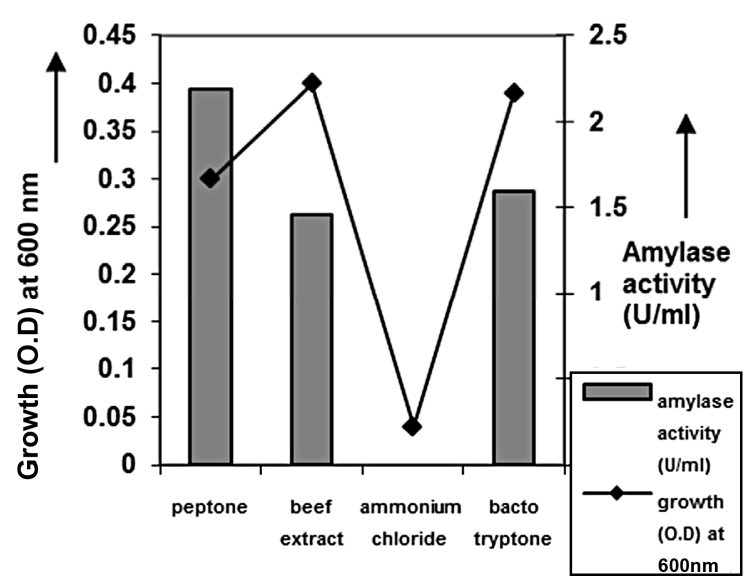

Figure 5. Nitrogen source optimization of $\mathrm{C}_{2}$.

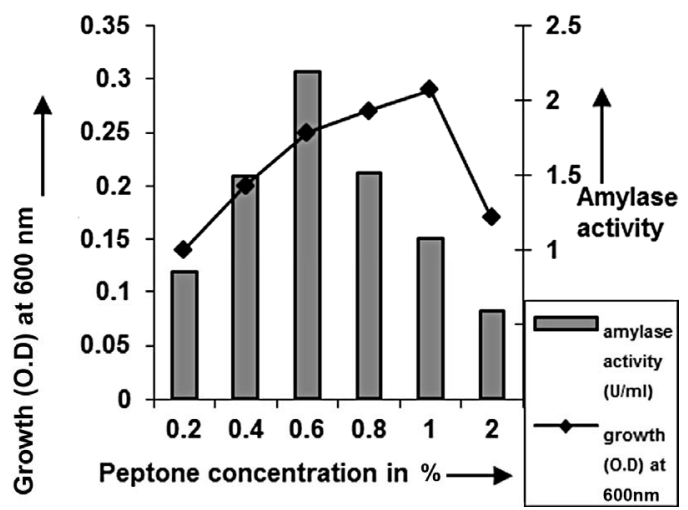

Figure 6. Peptone concentration optimization of $\mathrm{C}_{2}$.

Amylase activity and stability: Studies on crude enzyme characterization revealed that optimum activity was at $\mathrm{pH} 8$ and $37^{\circ} \mathrm{C}$ for $\mathrm{C}_{2}$ (Figures 11 and 12). The crude enzyme was stable for $24 \mathrm{~h}$ at $\mathrm{pH}$ range of $6-8$ at $37^{\circ} \mathrm{C}$. The enzymes were quite stable at $40^{\circ} \mathrm{C}$, while at $50^{\circ} \mathrm{C}$, the enzyme activity was lost. Enzyme activity elevated with temperature within the range of $40^{\circ} \mathrm{C}-37^{\circ} \mathrm{C}$. A reduction in enzyme activity was observed at temperatures

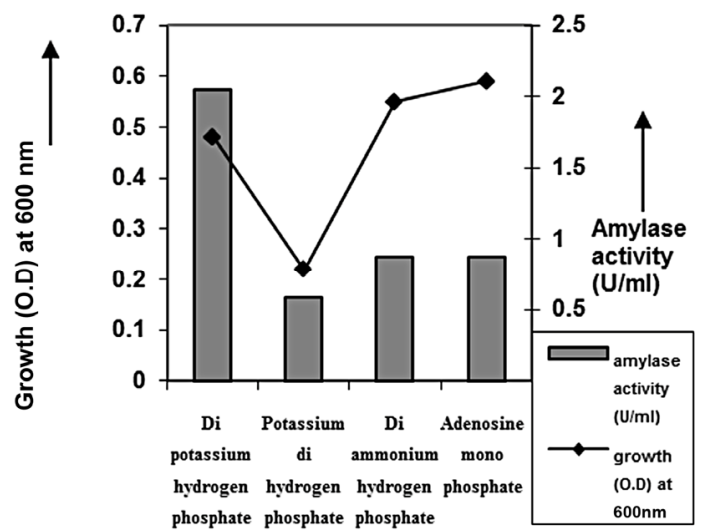

Figure 7. Phosphate source optimization of $\mathbf{C}_{2}$.

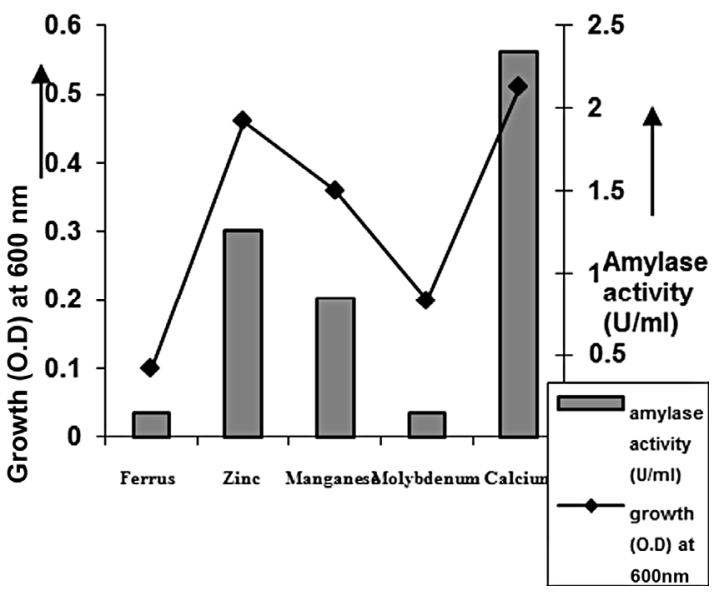

Figure 8. Metalion optimization of $\mathbf{C}_{2}$.

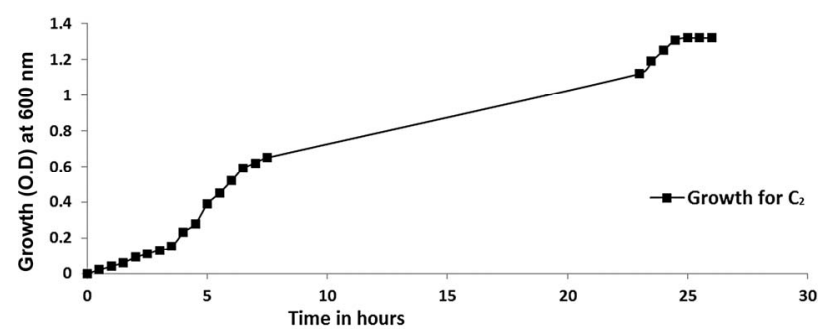

Figure 9. Time vs. growth.

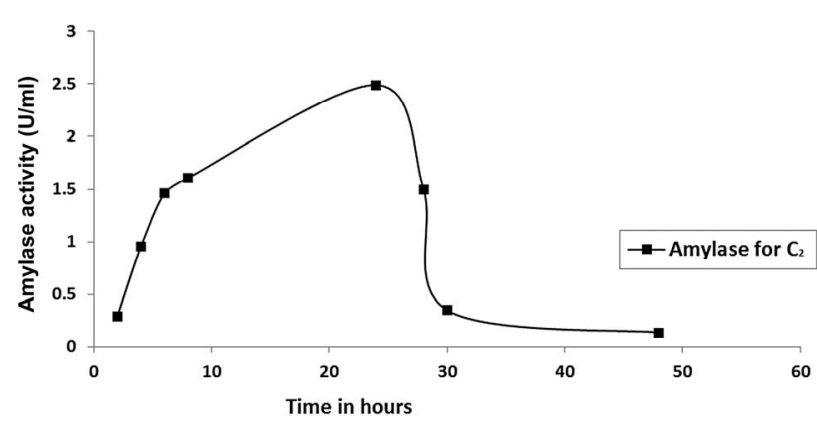

Figure 10. Time vs. amylase production.

above $40^{\circ} \mathrm{C}$.

Conclusions: Municipal waste management is a haz- 


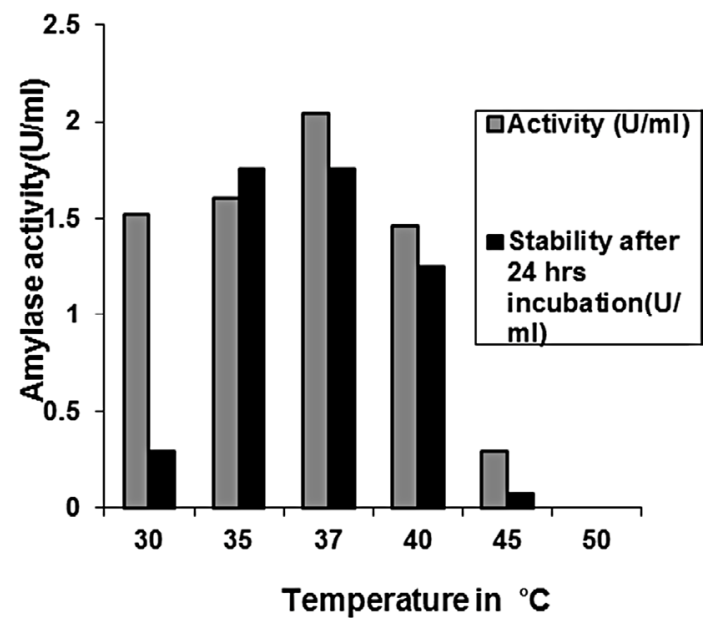

Figure 11. Effect of temperature on activity and stability of amylase from $\mathrm{C}_{2}$.

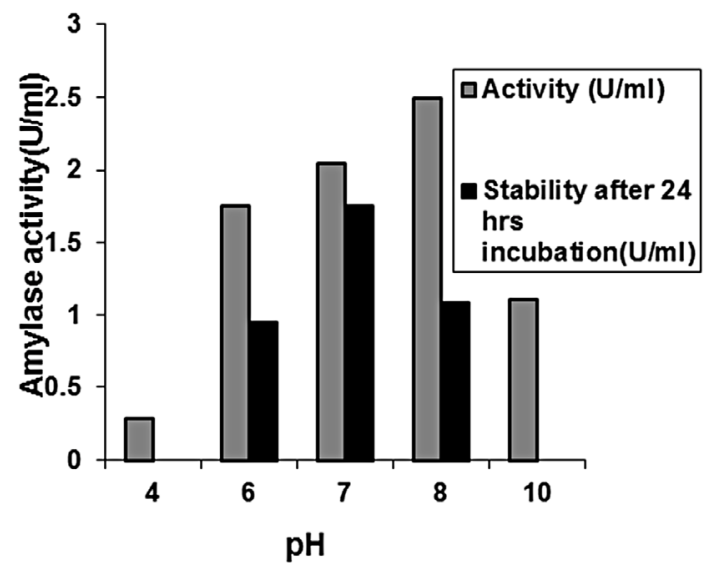

Figure 12. Effect of pH on activity and stability of amylase from $\mathrm{C}_{2}$.

ardous problem and one of the primal reasons of environmental pollution as well. It consists of different irritant household and industrial wastes; thus the quite justifiably the main target for environmentalists for their crusade against pollution. Municipal waste require disposal by incineration or land filling, from which eventually many social and environmental problems may arise. The conversation of organic waste through microbial process decreases landfilling by waste disposal and also produces ecofriendly compost which can be used as fertilizer [32]. Most importantly, enzymes are playing an important role as biological catalyst in the chemical transformation of this waste without affecting the environment. Amylase producing bacteria which are able to convert the starchy materials into different sugars can be one of the remarkable molecular devices in this context. The bacteria themselves were intentionally isolated from the municipal waste as they can innately tolerant to adverse environment like high $\mathrm{pH}$, large amount of heavy metal etc. and can be grown luxuriously in the solid wastes for their biochemical conversion. Undoubtedly, our present investigation on amylase producing bacteria can be successfully used for large scale bioconversion of starchy materials present in municipal waste which has a beneficial role in waste management. The bacteria were able to tolerate the adverse condition like wide range of $\mathrm{pH}$ and temperature and have significant toxic metal ion tolerance. On the other hand, Amylase from fungal source is the first industrially produced enzyme used as a pharmaceutical aid for treatment of digestive disorder. Although they can be isolated from different sources like plant, animals; amylases from microbial sources have greater stabilities which meet the industrial demands in food and textile processing. With the advent of new frontiers in biotechnology, the spectrum of amylase application has broadened in many other fields such as chemical, analytical and medicinal chemistry. In our study the organisms were giving amylases which are able to tolerate temperature up to $40^{\circ} \mathrm{C}$ and $\mathrm{pH} 6$ - 8. These characteristics are good enough to make them applicable for industrial purpose. Future study on isolation of more thermo stable bacteria from municipal waste will definitely propitious for both industrial use and waste management purposes across the globe.

\section{Acknowledgements}

Authors are pleased to acknowledge the Xcelris Labs Ltd. (Sydney House, Ahmedabad, India) for identification of microbial culture using $16 \mathrm{~S}$ rDNA based molecular technique.

\section{REFERENCES}

[1] H. Z. Zaved, M. Mizanur Rahman, M. Mashiar Rahman, A. Rahman, S. M. Y. Arafat and M. Safiur Rahman, "Isolation and Characterization of Effective Bacteria for Solid Waste Degradation for Organic Manure,” KMITL Science and Technology Journal, Vol. 8, No. 2, 2008, pp. 44-55.

[2] S. Cointreau, "Environmental Management of Urban Solid Wastes in Developing Countries-A Project Guide," Urban Development, World Bank, Washington DC, 1982.

[3] S. Arlosoroffs, "WB/UNDP Integrated Resource Recovery Project: Recycling of Wastes in Developing Countries,” In: K. Curi, Ed., Appropriate Waste Management for Developing Countries,” Plemum Press, New York, 1982.

[4] G. E. Blight and C. M. Mbande, "Some Problems of Waste Management in Developing Countries," Journal of Solid Waste Technology and Management, Vol. 23, No. 1, 1996, pp. 19-27.

[5] A. Burhan, U. Nisa, C. Gokhan, C. Omer, A. Ashabil and G. Osman, "Enzymatic Properties of a Novel Thermostable, Thermophilic, Alkaline and Chelator Resistant Amylase from an Alkaliphilic Bacillus sp. Isolate ANT-6," Process Biochemistry, Vol. 38, No. 10, 2003, pp. $1397-$ 
1403. doi:10.1016/S0032-9592(03)00037-2

[6] P. Ellaiah, K. Adinarayana, M. Sunitha and R. B. Devi, "Isolation of $\alpha$-Amylase Producing Fungi from Some Soils in India," Indian Journal of Microbiology, Vol. 43, No. 2, 2003, pp. 135-137.

[7] H. Vahidi, B. Shafagi and Z. Mirzabeigi, "Culture Medium Optimization of $\alpha$-Amylase Producing Organism Mocur spp. Using the Variable Size-Simplex Algorithm,” Daru, Vol. 13, No. 1, 2005, pp. 20-22.

[8] S. Chadha, K. Rubinder and H. S. Saini, "Constitutive Alpha-Amylase Producing Mutant and Recombinant Haploid Strains of Thermophilic Fungus Thermomyces Lanuginosus,” Folia Microbiologica, Vol. 50, No. 2, 2005, pp. 133-140.

[9] M. B. Ali, M. Mezghani and S. Bejar, “A Thermostable Producing Maltohexaose from a New Isolated Bacillus sp. US100: Study of Activity and Molecular Cloning of the Corresponding Gene,” Enzyme and Microbial Technology, Vol. 24, No. 8-9, 1999, pp. 584-589. doi:10.1016/S0141-0229(98)00165-3

[10] N. T. Mai, D. T. Giang, N. T. N. Minh and V. T. Thao, "Thermophilic Amylase-Producing Bacteria from Vietnamese Soils," World Journal of Microbiology and Biotechnology, Vol. 8, No. 5, 1992, pp. 505-508. doi:10.1007/BF01201949

[11] N. Abbas, "Isolation and Identification of $\alpha$-Amylase Producing Bacteria from Soil at NWFP (Pakistan)," New Biotechnology, Vol. 25, No. 1, 2009, p. S51. doi:10.1016/j.nbt.2009.06.262

[12] J. F. Shaw, F. P. Lin, S. C. Chen and H. C. Chen, "Purification and Properties of an Extracellular $\alpha$-Amylase from Thermus sp.," Botanical Bulletin of Academia Sinica, Vol. 36, No. 3, 1995, pp. 195-200.

[13] A. Pandey, P. Nigam, C. R. Soccol, V. T. Soccol D. Singh and R. Mohan, "Advances in Microbial Amylases,” Biotechnology and Applied Biochemistry, Vol. 31, 2000, pp. 135-152. doi:10.1042/BA19990073

[14] S. Mishra and N. Behera, "Amylase Activity of a Starch Degrading Bacteria Isolated from Soil Receiving Kitchen Wastes," African Journal of Biotechnology, Vol. 7, No. 18, 2008, pp. 3326-3331.

[15] H. Collins and P. M. Lyne, "Microbiological Methods," Butter Worths, Boston, 1976, p. 450.

[16] S. Thippeswamy, K. Girigowda and V. H. Mulimani, "Isolation and Identification of Alpha-Amylase Producing $\mathrm{Ba}$ cillus sp. from Dhal Industry Waste," Indian Journal of Biochemistry \& Biophysics, Vol. 43, No. 5, 2006, pp. 295298.

[17] D. Jamieson, K. M. Pruitt and R. C. Caldwell, “An Improved Amylase Assay,” Journal of Dental Research, Vol. 48, No. 3, 1969, p. 483. doi:10.1177/00220345690480032701

[18] N. Riaz, I. Haq and M. A. Qadeer, "Characterization of $\alpha$ Amylase by Bacillus subtilis," International Journal of Agriculture and Biology, Vol. 5, No. 3, 2003, pp. 249-252.

[19] P. V. D. Aiyer, "Effect of C: N Ratio on Alpha Amylase Production by Bacillus licheniformis SPT 27," African Journal of Biotechnology, Vol. 3, No. 10, 2004, pp. 519-
522.

[20] A. O. Ajayi and O. E. Fagade, "Utilization of Corn Starch as Substrate for $\beta$-Amylase by Bacillus sp.," African Journal of Biomedical Research, Vol. 6, No. 1, 2003, pp. 3742.

[21] H. Sugita, J. Kawasaki and Y. Deguchi, "Production of Amylase by the Intestinal Microflora in Cultured Freshwater Fish,” Letters in Applied Microbiology, Vol. 24, No. 2, 1997, pp. 105-108. doi:10.1046/j.1472-765X.1997.00360.X

[22] S. Aiba, K. Kitai and T. Imanaka, "Cloning and Expression of Thermostable $\alpha$-Amylase Gene from Bacillus stearothermophilus in Bacillus stearothermophilus and $B a-$ cillus subtilis," Applied and Environmental Microbiology, Vol. 46, No. 5, 1983, pp. 1059-1065.

[23] R. Gupta, P. Gigras, H. Mohapatra, V. K. Goswami and B. Chauhan, "Microbial $\alpha$-Amylases: A Biotechnological Prospective,” Process Biochemistry, Vol. 38, No. 11, 2003, pp. 1599-1616. doi:10.1016/S0032-9592(03)00053-0

[24] A. K. Chandra, S. Medda and A. K. Bhadra, "Production of Extracellular Thermostable $\alpha$-Amylase by Bacillus $l i$ chenifermis," Journal of Fermentation Technology, Vol. 58, No. 1, 1980, pp. 1-10.

[25] R. A. K. Srivastava and J. N. Baruah, “Culture Conditions for Production of Thermostable Amylase by Bacillus stearothermophilus," Applied and Environmental Microbiology, Vol. 52, No. 1, 1986, pp. 179-184.

[26] S. M. Ryan, G. F. Fitzgerald and D. Van Sinderen, "Screening for and Identification of Starch-, Amylopectin-, and Pullulan-Degrading Activities in Bifidobacterial Strains," Applied and Environmental Microbiology, Vol. 72, No. 8, 2006, pp. 5289-5296. doi:10.1128/AEM.00257-06

[27] R. A. K. Srivastava and S. N. Mathur, "Regulation of Amylase Bio-Synthesis in Growing and Non-Growing Cells of Bacillus stearothermophilus," Journal of Applied Microbiology, Vol. 57, No. 1, 2008, pp. 147-151. doi:10.1111/j.1365-2672.1984.tb02367.x

[28] J. L. Meers, "The Regulation of $\alpha$-Amylase Duction in Bacilhs licheniformis," Antonie van Leeuwenhoek Journal of Microbiology and Seroloyy, Vol. 38, No. 1, 1972, pp. 585-590.

[29] P. Schaeffer, “Asporogenous Mutants of Bacillus subtilis Marburg,” Folia Microbiologica, Vol. 2, No. 3, 1967, pp. 291-296. doi:10.1007/BF02868746

[30] J. P. Smits, A. Rinzema, J. Tramper, H. M. Van Sonsbeek and W. Knol, "Solid-State Fermentation of Wheat Bran by Trichoderma Reesei QM9414: Substrate Composition Changes, C Balance, Enzyme Production, Growth and Kinetics," Applied Microbiology and Biotechnology, Vol. 46, No. 5, 1996, pp. 489-496.

[31] K. Bose and D. Das, "Thermostable $\alpha$-Amylase Production Using B. licheniformis NRRL B1438," Indian Journal of Experimental Biology, Vol. 34, No. 12, 1996, pp. 1279- 1282.

[32] J. F. Parr and S. B. Hornick, "Utilization of Municipal Wastes,” In: F. B. Metting, Ed., Soil Microbial Ecology: Applications in Agricultural and Environmental Management, Marcel Dekker, Inc., New York, 1992, pp. 545-559. 